\title{
Is Networked Learning Postdigital Education?
}

\author{
Maarten de Laat ${ }^{1} \cdot$ Nina Bonderup Dohn ${ }^{2}$
}

As members of the Scientific Committee of the biannual International Conference on Networked Learning, we are pleased with the birth of this new journal focusing on the nature of a postdigital agenda. We welcome its aim of not only fostering research by publication in this area but also offering a platform for discussion to develop a muchneeded academic discourse. For this inaugural issue, we were approached to write a response to the editorial announcing the journal (Jandrić et al. 2018) and we are grateful for the opportunity.

Is networked learning postdigital education? may seem a rhetorical question-if 'networked' means 'digitally mediated', it would seem obvious that the answer is no. However, given the editorial description and discussion of the meaning of postdigital, the question appears less rhetorical (and the answer therefore less obvious): 'post' should not be taken in the sense of 'postmodernism' (as transcending and negating modernism), but as highlighting the fact that in contemporary society, 'the digital' is an integrated part of living. Hence, discussions of e.g. learning building on distinctions between 'the digital' and 'the physical' are becoming increasingly inaccurate and increasingly uninteresting or less meaningful. In this response, we would like to reflect on the postdigital from within the domain of networked learning rather than education: Even within networked learning, it is now difficult to make generalisations on the state of digitally mediated learning through networks.

An early definition of networked learning is: 'learning in which information and communications technology (ICT) is used to promote connections: between one learner and other learners, between learners and tutors, between a learning community and its resources' (Goodyear et al. 2004: 1). As indicated in the editorial (Jandrić et al. 2018), this definition, with its focus on ICT, would seem to make precisely that demarcation of the digital from the physical which the term 'postdigital' seeks to

Maarten de Laat

mdelaat@uow.edu.au

Nina Bonderup Dohn

nina@sdu.dk

1 University of Wollongong, Wollongong, Australia

2 University of Southern Denmark, Kolding, Denmark 
transcend. It should be stressed, though, that ICT is viewed as a means to an end (promoting connections), not an end in itself, despite its central position in the definition. Technology may enhance learning (in many shapes or forms) through promoting connections, and the early definition of networked learning helped to emphasise this. From the early nineties, it has inspired studies of online spaces designed for learning (including web-based and mobile technologies), ranging from early virtual learning environments to modern versions of MOOCs aimed at supporting formal and informal learning as well as the so-called learning in the wild taking place in various forms of digital social media.

However, in part due to the openness of the definition, different understandings of networked learning have developed over the years, most of which align more clearly with a view of learning as 'postdigital'. Dohn et al. (2018) identified four such understandings. The first of these emphasises the connections between people, investigating how people develop, maintain and learn from a 'web' of social relations (De Laat 2012). This understanding of networked learning does not necessarily involve ICT, though in specific cases it of course makes use of technology (Dohn et al. 2018: 204). In this approach, technology is viewed as part of the social networked structure through which people organise themselves to 'mediate' learning. In other words, technology is an accepted practice and part of the way these networks learn, in alignment with 'postdigital' views.

A second understanding emphasises connections between situations or contexts (Dohn et al. 2018). It investigates learning arising from the connections drawn by learners between situations and from their re-situated use of knowledge across contexts (Dohn 2014). ICT mediation is not a prerequisite, but - in the 'postdigital' world of today - will in fact quite often facilitate learners in drawing these connections.

A third understanding focuses on ICT infrastructure and the way it enables connections across time and space. In this approach, learning is networked whenever it is ICT-mediated or not (Swinnerton et al. 2018). The approach, however, does not presuppose a distinct digital learning space. On the contrary, it investigates how technology can facilitate mobile and boundary crossing between places of learning. It thus allows for the 'postdigital' point that these places may well be hybrid mergers of the physical and the virtual.

A final understanding that Dohn et al. (2018) identify stems from the socio-material approach of actor-network theory (ANT). It focuses on connections between actants, consisting of both human and non-human entities, and emphasises the need to understand situations - including learning situations - as entanglement of people and objects (Fox 2005). Learning, by taking place in entanglements, is therefore always 'networked'. With this emphasis on entanglement, the approach is fully able to accommodate a 'postdigital' claim that the digital is an interwoven part of living in today's world.

Beneath these differences in understandings of networked learning, there is a fundamental agreement on underlying points, traceable also to research based on the early definition: 'Networked learning as a research field stresses the importance of both human and digitally mediated interactions through the notion of "connections" and underlines that interactions with technologies and resources in isolation are not sufficient to constitute networked learning.' (De Laat and Ryberg 2018: 3). It has a humanistic and critical tradition (Hodgson et al. 2014; Jandrić and Boras 2015) treating 
learning as social and exploring human agency within this. Networked learning takes place in communities and networks, through shared practices, and is driven by social interaction and dialogue. A central debate through all the years has been the pedagogical values, beliefs and designs underpinning networked learning. The networked learning community has thus always preferred a pedagogical debate over a technology-driven innovation agenda in education and learning, but has accepted technology as being (an essential) part of it.

To conclude from the above, within networked learning, there has always been a strong acceptance of technology as an integrated factor in learning and learning design. This acceptance has even heightened over the years, with research increasingly focusing on how learners intermingle physical, virtual, social and personal settings, in their engagement in and across formal and informal learning situations. The development within the research field of Networked Learning therefore aligns very well with the editorial's stress on the digital as interwoven in the 'messiness (...) inherent to the contemporary human condition' (Jandrić et al. 2018: 895).

Actually, in one respect, we find that networked learning, by broadening its original focus on formal education to include also learning in and across a range of informal settings, has gone further in acknowledging this messiness than the editorial to the inaugural issue seems to do (Jandrić et al. 2018). Indeed, we are somewhat surprised at the fairly traditional view of education - as learning taking place within formal educational programmes - presented in the editorial. It seems to us that the editors have missed the opportunity of asking what the 'postdigital' messiness could mean in terms of intermingling learning situations beyond formal institutional boundaries. A postdigital approach, from our point of view, would (very much in line with developments within networked learning) shift its focus away from educational silos and discussions of disruptive technology towards the question how the learner may be liberated in a world of hybrid learning spaces (e.g. Oliver and Gourlay 2016). Key points here would be the use of technology to provide (open) access to (human and non-human) networked resources, fluidity in terms of whom to learn with, when, how, why and for how long, freed from strict location requirements. Unbundling of traditional educational services and institutions (Swinnerton et al. 2018) and hybrid formal and informal uses of MOOCs and forms of lifelong learning are further examples.

In sum, the question Is networked learning postdigital education? is far from rhetorical, and the answer certainly is not no. Neither is it, however, a clear yes. For one thing, today as before, the early definition still fosters an interest within the community in 'online courses with individuals sitting in their homes, connected through desktop computers and increasingly more diverse technology enhanced learning settings' (Jandrić et al. 2018: 895). Quite as importantly, if drawing on the definition of Postdigital Education presented in the editorial, Networked Learning actually moves beyond it in terms of the learning spaces it embraces. There is certainly a large overlap in focus areas and underlying assumptions between Networked Learning and Postdigital Education, but - it would seem-Networked Learning sometimes allows more 'messiness' than editors of Postdigital Science and Education envisage. Be that as it may, we hope with this piece to have given a nuanced interpretation of the place technology has in networked learning - and one that in our opinion sits quite comfortably in the postdigital era... 


\section{References}

De Laat, M. (2012). Enabling professional development networks: How connected are you? Heerlen: LOOK, Open Universteit of the Netherlands.

De Laat, M., \& Ryberg, T. (2018). Celebrating the Tenth Networked Learning Conference: looking back and moving forward. In N. B. Dohn, S. Cranmer, J.-A. Sime, M. de Laat, \& T. Ryberg (Eds.), Networked Learning: reflections and challenges (pp. 1-20). Cham: Springer International Publishing. https://doi. org/10.1007/978-3-319-74857-3_1.

Dohn, N. B. (2014). Implications for networked learning of the 'practice' side of social practice theories - a tacit-knowledge perspective. In V. Hodgson, M. de Laat, D. McConnell, \& T. Ryberg (Eds.), The design, experience and practice of networked learning (pp. 29-49). Dordrecht: Springer.

Dohn, N. B., Sime, J.-A., Cranmer, S., Ryberg, T., \& De Laat, M. (2018). Reflections and challenges in Networked Learning. In N. B. Dohn, S. Cranmer, J.-A. Sime, T. Ryberg, \& M. De Laat (Eds.), Networked Learning: reflections and challenges (pp. 187-212). Cham: Springer. https://doi.org/10.1007/978-3-31901940-6 2.

Fox, S. (2005). An actor-network critique of community in higher education: implications for networked learning. Studies in Higher Education, 30(1), 95-110. https://doi.org/10.1080/0307507052000307821.

Goodyear, P., Banks, S., Hodgson, V., \& McConnell, D. (Eds.). (2004). Advances in research on Networked Learning. Dordrecht: Kluwer Academic.

Hodgson, V., de Laat, M., McConnell, D., \& Ryberg, T. (2014). Researching design, experience and practice of Networked Learning: an overview. In V. Hodgson, M. de Laat, D. McConnell, \& T. Ryberg (Eds.), The design, experience and practice of Networked Learning (pp. 1-26). Cham: Springer International Publishing. https://doi.org/10.1007/978-3-319-01940-6_1.

Jandrić, P., \& Boras, D. (Eds.). (2015). Critical learning in Digital Networks. Cham: Springer International Publishing.

Jandrić, P., Knox, J., Besley, T., Ryberg, T., Suoranta, J., \& Hayes, S. (2018). Postdigital science and education. Educational Philosophy and Theory, 50(10), 893-899. https://doi.org/10.1080 /00131857.2018.1454000.

Oliver, M., \& Gourlay, L. (2016). Students’ physical and digital sites of study: making, marking, and breaking boundaries. In L. Carvalho, P. Goodyear, \& M. De Laat (Eds.), Place-based spaces for Networked Learning (pp. 73-86). Abingdon: Routledge.

Swinnerton, B., Ivancheva, M., Coop, T., Perrotta, C., Morris, N. P., Swartz, R., ... Waji, S. (2018). The Unbundled University: Researching emerging models in an unequal landscape. Preliminary findings from fieldwork in South Africa. In M. Bajić, N. B. Dohn, M. de Laat, P. Jandrić, \& T. Ryberg (Eds.), Proceedings of the 11th International Conference on Networked Learning. Lancaster: Lancaster University. 